\title{
THE SYNCHRONIZATION OF OVULATION IN THE ADULT FEMALE RAT BY ORAL ADMINISTRATION OF MEGESTROL ACETATE
}

\author{
J. P. BENNETT,* D. K. VALLANCE AND B. H. VICKERY* \\ The Biological Research Department, B.D.H. (Research) Limited, \\ Godalming, Surrey
}

(Received 15th November 1966, revised 5th Fanuary 1968)

Summary. A synchronous rebound of ovulation has been shown in mature rats after cessation of dosing with megestrol acetate. Over a period of 24 to $36 \mathrm{hr}, 3$ days after cessation of dosing, 95\% of the rats studied ovulated. The possible significance of this finding is discussed.

\section{INTRODUCTION}

The use of progestins to synchronize ovulation for the artificial insemination of farm animals is potentially of great importance. Hansel $(1959,1961)$ showed that daily injections of 50 to $100 \mathrm{mg}$ of progesterone from mid-cycle onwards prevented oestrus and ovulation from occurring in cattle until 4 to 7 days after cessation of treatment. Other workers who have contributed to this field of study in cattle include Christian \& Casida (1948), Willett (1950), Trimberger \& Hansel (1955) and Ulberg (1955). However, all these workers found that low conception rates resulted from the rebound oestrus. Synchronization of ovulation and oestrus in the ewe (following cessation of daily injections of $10 \mathrm{mg}$ of progesterone) was first described by Dutt \& Casida (1948). Their work has been confirmed and extended by Hunter (1953) and Robinson (1954, $1956,1959)$. More recently there has been increasing interest in the search for orally-active synthetic progestins capable of effective synchronization of ovulation and oestrus in cattle and sheep (Zimbelman, 1961; Dzuik, 1962; Bindon \& Roberts, 1964; Zimbelman \& Smith, 1966a, b).

Previous studies in this laboratory (David, Edwards, Fellowes \& Plummer, 1963) demonstrated the ovulation-inhibiting activity in the rabbit of the potent oral progestational steroid, megestrol acetate (17 $\alpha$-acetoxy-6-methylpregna-4:6-diene-3:20-dione). The compound has now been examined for ability to synchronize ovulation in the rat when administered by the oral route.

\section{MATERIALS AND METHODS}

Specific pathogen-free female albino rats, 7 to 8 weeks of age and weighing 200 to $250 \mathrm{~g}$, were obtained from our own colony which originated from

\footnotetext{
* Present address: Institute of Hormone Biology, Syntex Research, Stanford Industrial Park, Palo Alto, California, U.S.A.
} 
Sprague-Dawley, Caesarian-derived, barrier-sustained stocks of the Charles River Breeding Laboratories Inc., U.S.A. The rats were housed in rooms with a 14:10 hr light:dark schedule.

One hundred animals were dosed orally with megestrol acetate $(12 \mathrm{mg} / \mathrm{kg})$ for 7 days consecutively. The compound was suspended in an aqueous medium containing $1.2 \% \mathrm{w} / \mathrm{v}$ carboxymethyl cellulose, $1.59 \% \mathrm{w} / \mathrm{v}$ Tween 80 and distilled water to $100 \%$, and the dose volume was adjusted to $25 \mathrm{ml} / \mathrm{kg}$. A further 100 animals were given the vehicle alone.

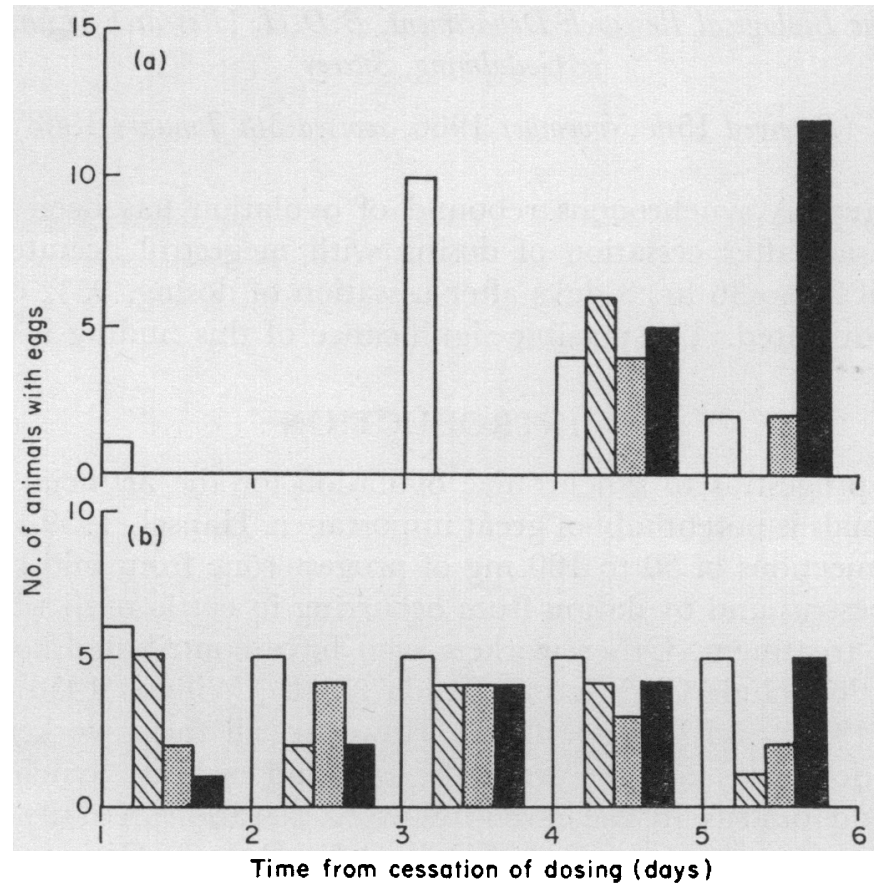

TEXT-FIG. 1. (a) Megestrol acetate, $12 \mathrm{mg} / \mathrm{kg} / \mathrm{day}$; (b) vehicle control. Position of eggs in Fallopian tube: open columns, first quarter; cross-hatched columns, second quarter; stippled columns, third quarter; solid columns, fourth quarter.

Twenty treated and twenty control rats were then autopsied each day for 5 days consecutively after cessation of dosing. The Fallopian tubes were removed, straightened by dissection and mounted in physiological saline beneath a cover slip upon a microscope slide. The positions of the eggs contained within the Fallopian tube were determined under the microscope.

\section{RESULTS}

The numbers of animals ovulating and the positions of the eggs within the Fallopian tubes during each of the 5 consecutive days after withdrawal of megestrol acetate are shown in Table 1 and Text-fig. 1, respectively. Ovulation was completely suppressed in the treated animals (with one exception) on the 1st and 2nd days after cessation of dosing, but on the 3rd day eggs appeared in $50 \%$ of the animals. The eggs were observed in the first quarter of the Fallopian tube and were completely surrounded by cumulus cells. By the 4 th day, 
$95 \%$ of the animals had ovulated and the eggs were evenly distributed throughout the length of the Fallopian tubes. In contrast, no trend to synchronization of ovulation was observed in the control animals. Eggs were observed in 65 to $85 \%$ of the control rats on each day and were randomly distributed throughout the length of the Fallopian tubes.

\section{TABLE 1}

SYNCHRONIZATION OF OVULATION IN THE RAT AFTER GESSATION OF DOSING WITH MEGESTROL ACETATE

\begin{tabular}{l|c|ccccc}
\hline \multirow{2}{*}{ Compound } & \multirow{2}{*}{$\begin{array}{c}\text { Dose } \\
(\mathrm{mg} / \mathrm{kg} /\end{array}$} & \multicolumn{5}{|c}{ Day after cessation of dosing } \\
\cline { 3 - 6 } & day $)$ & \multicolumn{5}{|c}{ No. of animals with eggs } \\
\hline Megestrol acetate & 12 & 1 & 0 & 10 & 19 & 16 \\
Vehicle control & - & 14 & 13 & 17 & 16 & 13 \\
\hline
\end{tabular}

All groups contained twenty animals.

The number of dosed animals with eggs in the Fallopian tubes during the experiment was significantly different from the undosed controls on a $\chi^{2}$ analysis $(P<0.001)$.

\section{DISCUSSION}

Oral administration of megestrol acetate has proved highly effective in synchronizing ovulation in the rat, $95 \%$ of the animals ovulating on the 3rd or 4th day after cessation of dosing. A similar, although less effective, synchronization by progesterone has been previously reported by Doyle \& Clegg (1961) with $75 \%$ of females being mated by Day 4 after cessation of dosing, and by Hoffman \& Schwartz $(1964,1965)$ with ovulation occurring in $50 \%$ of the rats by Day 5 after cessation of dosing.

Many attempts have been made to elucidate the mechanism of action of progesterone and, as early as 1938, Astwood \& Fevold concluded from indirect evidence that exogenous progesterone inhibits ovulation and oestrus by suppressing release of pituitary luteinizing hormone $(\mathrm{LH})$. This hypothesis has been supported more recently by Van Rees (1959), who found a lowered serum LH level in progesterone-dosed rats, and by Hoffman \& Schwartz (1965), who showed the LH content of the pituitaries of progesterone-dosed rats to be higher than normal pro-oestrous levels for animals of the same strain. The question of whether follicle stimulating hormone (FSH) is also involved is the subject of conflicting reports in the literature. Van Rees (1959) reported that repeated administration of progesterone for 25 to 27 days increased the FSH content of the pituitary while decreasing its readiness to release FsH. Other workers, however, have concluded that normal release of FSH occurs during inhibition of ovulation by progesterone (Everett, 1961; Peterson, Edgren \& Jones, 1964; Kaufman \& Rothchild, 1966). Support for this conclusion is afforded by the work of Greep \& Jones (1950) who demonstrated the presence of Graafian follicles in the ovaries at all times during ovulation inhibition by progesterone. 
There is a relative lack of information concerning the mechanisms involved in inhibition and return of ovulation as a consequence of treatment with megestrol acetate, although the close similarity in chemical structure suggests that they might correspond to those involved in the case of progesterone. Some support for this suggestion may be obtained from the conclusions of Kobayashi, Kobayashi, Takezawa, Oshima \& Kawamura (1962) that progesterone and megestrol acetate act similarly with respect to ovulation blockade in the rat, at least in part, by suppressing the activity level of the posterior hypothalamus and limbic midbrain area. A further pointer is the observation that ovulation blockade due to continuing treatment with megestrol acetate may be overcome by injection of LH (Bennett, Vallance \& Vickery, 1968).

The results reported above encourage the belief that successful synchronization of oestrus and ovulation in domestic animals may be achieved by treatment with megestrol acetate. This possibility is now under active investigation.

\section{REFERENCES}

Astwood, E. B. \& FEVOLD, H. L. (1938) The action of progesterone on the gonadotrophic activity of the pituitary. Am. J. Physiol. 192, 127.

Bennett, J. P., Vallance, D. K. \& Vickery, B. H. (1968) Investigation of block to gonadotrophin release in mature female rats. F. Reprod. Fert. 15, 233.

Bindon, B. M. \& RoBerts, E. M. (1964) The control of ovarian activity in ewes with progestagens. F. Reprod. Fert. 7, 397.

Christian, R. E. \& Gasida, L. E. (1948) The effects of progesterone in altering the oestrous cycle of the cow. F. Anim. Sci. 7, 540 .

David, A., Edwards, K., Fellowes, K. P. \& Plummer, J. M. (1963) Anti-ovulatory and other biological properties of megestrol acetate, $17 \alpha$-acetoxy-6 methyl pregna 4:6-diene-3:20-dione (BDH 1298). F. Reprod. Fert. 5, 331.

Doyle, D. L. \& CLEGG, M. T. (1961) Effect of progesterone withdrawal on time of oestrus and mating behaviour in female rats. F. Reprod. Fert. $2,143$.

DutT, R. H. \& Casida, L. E. (1948) Alteration of the oestrual cycle in sheep by use of progesterone and its effect upon subsequent ovulation and fertility. Endocrinology, 43, 208.

Dzurk, P. (1962) Control of oestrus or ovulation in farm animals with the aid of orally active progestins. F. Endocr. 24, xxi.

Everetr, J. W. (1961) Sex and internal secretions, pp. 497 et seq. Ed. W. C. Young. Williams \& Wilkins, Baltimore.

Greep, R. O. \& Jones, I. C. (1950) Steroid control of pituitary function. Recent Prog. Horm. Res. 5, 197.

Hanset, W. (1959) Reproduction in domestic animals, Vol. I, p. 250. Eds. H. H. Cole and P. T. Cupps. Academic Press, New York.

Hansel, W. (1961) Oestrus cycle and ovulation control in cattle. F. Dairy Sci. 44, 2307.

Hofrman, J. C. \& Schwartz, N. B. (1964) 'Progesterone-withdrawal' ovulation in the rat. Fedn Proc. Fedn Am. Socs exp. Biol. 23, 109.

Hofpman, J. C. \& Schwartz, N. B. (1965) Timing of ovulation following progesterone withdrawal in the rat. Endocrinology, 76, 625 .

Hunter, G. L. (1953) Attempts to synchronize the occurrence of oestrus in sheep as a preliminary to ovum transplantation. F. Endocr. 10, xiii.

Kaufman, A. B. \& Rothchild, I. (1966) The corpus luteum-hypophysis relationship; the effect of progesterone treatment on the release of gonadotrophins in the rat. Acta endocr., Copenh. 51, 231.

Kobayashi, T., Kobayashi, T., Takezawa, S., Oshima, K. \& Kawamura, H. (1962) Electrophysiological studies on the feedback mechanism of progesterone. Endocr. jap. 9, 302.

Peterson, D. L., Edgren, R. A. \& Jones, R. G. (1964) Steroid-induced block of ovarian compensatory hypertrophy in hemicastrated female rats. 7. Endocr. 29, 255.

RoBinson, T. J. (1954) The necessity for progesterone with oestrogen for the induction of recurrent oestrus in the ovariectomized ewe. $\mathcal{F}$. Endocr. 10, 117.

Rosinson, T. J. (1956) The artificial insemination of the merino sheep following the synchronization of oestrus and ovulation by progesterone injected alone and with pregnant mare serum gonadotrophin. Aust. 7. agric. Res. 7, 194. 
Robrnson, T. J. (1959) Reproduction in domestic animals, Vol. 1, p. 291. Eds. H. H. Cole and P. T. Cupps. Academic Press, New York.

Trumberger, G. W. \& Hanser, W. (1955) Conception rate and ovarian function following oestrus control by progesterone injections in dairy cattle. J. Anim. Sci. 14, 224.

Ulberg, L. C. (1955) Synchronisation of oestrus cycles. Proc. Cent. Symp. Reprod. Infert., p. 104. Michigan State University.

VAN REES, G. P. (1959) ICSH and FSH content of anterior pituitary and blood serum. Acta physiol. pharmac. neerl. 8, 195.

WrLLET, E. L. (1950) The fertility of heifers following administration of progesterone to alter the estrual cycle. 7. Dairy Sci. 33, 381.

Zmbelman, R. G. (1961) The control of oestrus and ovulation in heifers by orally administered $6 \alpha-$ methyl 17a-acetoxy progesterone. F. Dairy Sci. 44, 1195.

Zimbelman, R. G. \& SMrth, L. W. (1966a) Control of ovulation in cattle with melengestrol acetate. I. Effect of dosage and route of administration. 7. Reprod. Fert. 11, 185.

Zmbelman, R. G. \& SMrry, L. W. (1966b) Control of ovulation in cattle with melengestrol acetate. II. Effects on follicular size and activity. F. Reprod. Fert. 11, 193. 